\title{
ANTIFUNGAL POTENTIAL OF Lippia multiflora MOLD. AND Melaleuca leucadendron L. ESSENTIAL OILS AGAINST SOME ROOT BORNE FUNGI OF IPOMEA BATATAS (L) LAM. IN CÔTE D'IVOIRE
}

\author{
Tia Vama Etienne ${ }^{1}$, Cissé Mohamed ${ }^{2}$, Allani Sophie Aka Christiane ${ }^{3}$
}

\begin{abstract}
${ }^{1}$ Department of Biochemistry, Péléforo Gon Coulibaly University (UPGC) Côte d'Ivoire
${ }^{2}$ Department of Biochemistry, Péléforo Gon Coulibaly University (UPGC) Côte d'Ivoire

${ }^{3}$ Péléforo Gon Coulibaly University (UPGC) Côte d'Ivoire
\end{abstract}

Received - April 11, 2020; Revision - September 20, 2020; Accepted - October 19, 2020

Available Online - October 25, 2020

DOI: http://dx.doi.org/10.18006/2020.8(5).654.662

\author{
KEYWORDS \\ Antifungal activity \\ Essential oil \\ Sweet potato \\ Lippia multiflora \\ Melaleuca leucadendron
}

* Corresponding author

E-mail: etienne.tia@gmail.com (Tia Vama Etienne)

Peer review under responsibility of Journal of Experimental Biology and Agricultural Sciences.

Production and Hosting by Horizon Publisher India [HPI] (http://www.horizonpublisherindia.in/).

All rights reserved.

\begin{abstract}
The objective of this study was to evaluate the antifungal activity of Lippia multiflor and Melaleuca leucadendron essential oils against three phytopathogenic fungi (Rhizopus sp., Fusarim sp., and Aspergillus sp.) associated with Ipomea batatas tuberous. Essential oils had been extracted by steam distillation method from leaves of selected plants and their chemical composition was characterized by gas chromatography-mass spectrometry (GC-MS). Essential oil composition characterization was followed by the estimation of percentage mycelial growth inhibition, minimum inhibitory concentration, and minimum fungicidal concentration of the isolated essential oils against the tested pathogens by the Sabouraud dilution medium method. Antifungal activity of different concentrations of isolated essential oils was evaluated by using the microdilution method. The most abundant compounds identified in the M. leucadendron essential oil are 1,8-cineole (38.2\%), viridiflorol (13.4\%), $\alpha$-Pinene (12.5\%), $\alpha$-terpineol(9.2\%), and geranial $(22.8 \%)$ while L. multiflora essential oil have neral (18.7\%), 1,8-Cineole (11.4\%), $\alpha$-Phellandrene (6.8\%), sabinene $(3.5 \%)$ as active ingredients. The concentration of essential oils which completely inhibited the mycelial growth and spore germination of all the tested pathogen varies and it was reported $0.33 \mu \mathrm{L} / \mathrm{mL}$ and $0.66 \mu \mathrm{L} / \mathrm{mL}$ for L. multiflora respectively while it was reported $24 \mu \mathrm{L} / \mathrm{mL}$ for $M$. leucadendron, for both effect, seven days of incubation. The minimum concentration of fungicidal essential oil against Aspergillus $s p$. was $0.33 \mu \mathrm{L} / \mathrm{mL}$ for L. multiflora. The findings of the current study confirm the fungicidal properties of the tested essential oils and their potential use in the management of economically important fungal pathogens of Ipomea batatas. Further, these essential oils can be used as possible alternatives to synthetic fungicides.
\end{abstract}

All the articles published by Journal of Experimental Biology and Agricultural Sciences are licensed under a Creative Commons Attribution-NonCommercial 4.0 International License Based on a work at www.jebas.org.

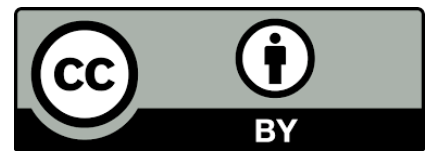




\section{Introduction}

The economies of African countries especially Côte d'Ivoire is mainly based on livestock and agricultural production. Among agricultural products, sweet potato is the seventh most important crop in the world after wheat, rice, maize, potato, barley, and cassava because of its high yield, high adaptability, and high strength (Yan et al., 2014). Sweet potatoes are rich in vitamins, minerals (mainly potassium), dietary fiber, and protein which provide higher energy and nutrition (Ndangui, 2015). Besides, more than $80 \%$ of its composition is carbohydrates, mainly in the form of starch (Nepa, 2006). Roots and tubers, including cassava, sweet potato, potato, and yam, are the main food crops for human consumption in Africa (Zannou et al., 2017). In Côte d'Ivoire, sweet potato has recently received much attention due to its many agricultural advantages such as its adaptability to different environmental conditions and its nutritional value. The annual production, which is self-consumed, is about 50,000 tonnes and is carried out by the Central and Northern regions of the country (Anonymous, 2009).

Sweet potato crop faces many biotic and abiotic stresses, among identified biotic stress, spongy and soft root rot disease of sweet potatoes is the most damaging one. Mould contamination of these roots can lead to the loss of marketability and sanitary qualities. Indeed, the development of moulds on sweet potatoes can lead to their discoloration and poor presentation. Also, moulds can produce allergenic and toxic metabolites (mycotoxins) that can penetrate the sweet potato and affect the health of the consumer (Nasser, 2001).

To protect crops and keep harvests healthy, farmers used chemical fungicides or pesticides to reduce the microbial load or to slow down biochemical alteration reactions, as well as the action of microorganisms. However, commonly used chemicals may, in the short or long term, pose a real risk of mutagenicity, chromosomal aberrations, and cancers to the consumers (Elkaketal., 2012). The need for an alternate strategy feels by researchers and makes various efforts to develop a low-cost method that is compatible with environmental concerns and can control the spreading of disease. The control of sweet potato root rot fungi by the application of natural fungicides has taken a very important place in alternative strategies to synthetic fungicides. In this sense, the study of secondary metabolites from plants is an interesting strategy for the protection of food against fungal parasites (Tomal et al., 2015).

Essential oils with their wide spectrum of action against a large number of fungal species are a very promising alternative, without being a source of danger to human health or pollution to the environment (Broydé \& Doré, 2013). The current study was aimed to establish the antifungal potential of two essential oils viz., $L$. multiflora and M. leucadendron against three main root rot fungi (Rhizopus sp., Aspergillus sp., and Fusarium sp.) isolated from the tuberous roots of sweet potatoes.

\section{Material and Methods}

\subsection{Extraction of essential oils}

L. multiflora leaves were collected at Tortya $\left(8^{\circ} 46^{\prime} \mathrm{N} ; 5^{\circ} 41^{\prime} \mathrm{O}\right)$ in the north while $M$. leucadendron leaves from San Pedro (4º4' $41^{\prime}$ N; $6^{\circ}$ $38^{\prime} 23^{\prime}$ O) regions, these two regions are located in the northern part and southern of Côte d'Ivoire respectively. The leaves of the selected plants were air-dried for seven days at room temperature under laboratory conditions $\left(28 \pm 2{ }^{\circ} \mathrm{C}\right)$. The essential oils were obtained from these dry leaves by steam distillation method. The essential oil yield was determined by processing $5 \mathrm{Kg}$ of dry leaves matter. The percentages of essential oil yield have been calculated as follow:

$$
\text { Yield }(\%)=\frac{\text { weight of essential oil }}{\text { Weight of leaves }} \times 100
$$

\subsection{Chemical composition of the isolated essential oils}

GC-MS analyses were performed on a Hewlett-Packard gas chromatography (GC 5890, SeriesII) equipped with a HP-5 fused silica capillary column (5\% phenyl $95 \%$ methylpolysiloxane :30 m x $0.25 \mathrm{~mm}$ i.d. $0.25 \mu \mathrm{m}$ ). The mass detector is a quadrupole type (model 5972). The temperature of the column is programmed between 70 to $200{ }^{\circ} \mathrm{C}$ at a rate of $10^{\circ} \mathrm{C} / \mathrm{min}$. The injector and transfer temperatures are $220^{\circ} \mathrm{C}$ and $250^{\circ} \mathrm{C}$ respectively. The carrier gas is Helium, the flow rate is fixed at $0.06 \mathrm{ml} / \mathrm{min} .1 \mu \mathrm{L}$ of an essential oil solution (10\% essential oil in ethylether) is injected in split mode (leakage ratio: 1/100). The ionization energy is equal to $70 \mathrm{eV}$; electron multiplier $1400 \mathrm{eV}$; scanning area [35-300 $\square$ $(\mathrm{m} / \mathrm{z})]$; scanning rate $2.96 \mathrm{scan} / \mathrm{s}$. The components were identified based on their retention index calculated by comparing retention times with those of a series of alkanes (C9-C22) and by comparing their mass spectra with those of the NBS 75 K/ NIST 98/WILEY 275 libraries (McLafferty, 1989). Some of the compounds from essential oil were confirmed by comparing their retention times with those of authentic standard substances and with data as reported by Adams (2007).

\subsection{Isolation and description of fungal test pathogens}

The three test pathogens were originally isolated from the naturally infected root of Ipomea batatas. Naturally infected tuberous roots are immersed for two minutes in a $1 \%$ potassium hypochlorite solution to remove surface saprophytic flora, it was followed by washing tubers three times by sterile distilled water. These roots segments were dried on sterile filter paper (Whatman) (Rosales \& Mew, 1997) before being cut into small pieces. These surfacesterilized root fragments are transferred to the Petri dishes 
supplemented with potato dextrose agar medium (PDA) $(15 \mathrm{~mL}$ per dish) and the dishes were incubated at $25^{\circ} \mathrm{C}$. To obtain pure single-spore culture, hyphal tips from the fungal cultures were subcultured onto Potato Dextrose Agar (PDA) and incubated at $25^{\circ} \mathrm{C}$. Confirmation of the identity of the resultant cultures was based on cultural and morphological characteristics (Samson et al., 2004; Domsch et al., 2007).

\subsection{Determination of the antifungal activity of essential oils}

The evaluation of the antifungal activity of essential oils is adopted by the direct contact method with various concentrations obtained by the addition of essential oils (dissolved in $0.5 \%(\mathrm{v} / \mathrm{v})$ of Tween80) at different doses upon $15 \mathrm{~mL}$ of Sabouraud with chloramphenicol $\left(45^{\circ} \mathrm{C}\right)$ in a sterilized Erlenmeyer flask. The final concentration used for current study are $\mathrm{C} 1=0.066 ; \mathrm{C} 2=0.166$; $\mathrm{C} 3=0.333$ and $\mathrm{C} 4=0.666 \mu \mathrm{L} / \mathrm{mL}$ for $L$. multiflora essential oil while it was used $\mathrm{C} 1=2.66 ; \mathrm{C} 2=5.33 ; \mathrm{C} 3=12 ; \mathrm{C} 4=24$ and $\mathrm{C} 5=48$ $\mu \mathrm{L} / \mathrm{mL}$ for the essential oil of $M$. leucadendron.

Agar disque with mycelia (6 $\mathrm{mm}$ in diameter) were cut from the periphery of actively growing regions of 5-7days-old pure cultures using a sterile cork borer and aseptically inoculated at the center of the sabouraud Petri plate containing PDA medium with essential oil. Control plates (without the essential oil) were inoculated by following the same procedure. Three replicates were maintained for each treatment and the plates were incubated at $28 \pm 2^{\circ} \mathrm{C}$. The fungal colony diameter reading was taken every day and up to seven days of incubation. The percentage inhibition of the mycelial growth of the test fungi by the essential oil was calculated using the formula given by Pandey et al., (1982):

$$
T(\%)=\left(\frac{\mathrm{dt}-\mathrm{dT}}{\mathrm{dt}}\right) \times 100
$$

T: inhibition rate

$\mathrm{dt}$ : average diameter of fungal colonies in the control

dT: average diameter of treated fungal colonies.

2.5 Determination of Minimum Inhibitory Concentration and Minimum Fungicidal Concentration

Minimum Inhibitory Concentration (MIC) was defined as the lowest concentration of essential oil at which fungal growth inhibited. The determination of the mycelial growth inhibition rate of each fungal strain made it possible to define the minimum inhibitory concentration (MIC). To determine the minimum fungicidal concentration (MFC) each mycelium was cut from the center of the dishes that did not show any visible fungal growth and inoculated in plates containing Sabouraud plates and these plates were incubated for 14 days at $28 \pm 2^{\circ} \mathrm{C}$. After 14 days of incubation at $28 \pm 2{ }^{\circ} \mathrm{C}$, the readings of MFCs were carried out based on the growth controls. The minimum fungicidal concentration was represented by the lowest essential oil concentration that hindered the visible growth of the subculture (did not yield any fungal growth on the solid medium used). MFC can be defined as the lowest concentration at which no growth was observed after sub-culturing into fresh media.

\subsection{Inhibitory effect on spore germination}

The evaluation of the antifungal activity was carried out using a slide germination test of spore as described by Doumbouya et al. (2012). Fungal spores were collected using sterile distilled water, from Sabouraud plates after 5 to 7 days of growth at $28 \pm 2{ }^{\circ} \mathrm{C}$. Based on the preliminary results on the antifungal activity of the essential oils tested, the concentrations used for the determination of MIC and MFC were chosen for the spore germination inhibition tests. These concentrations $(0.066$ to $0.66 \mu \mathrm{L} / \mathrm{mL}$ for $L$. multiflora and 2.66 to $48 \mu \mathrm{L} / \mathrm{mL}$ for $M$. leucadendron) were obtained by adding different doses of essential oils to the Sabouraud medium $(15 \mathrm{~mL})$ melted under agitation to facilitate the dispersion of natural compounds in the medium. The medium was poured into Petri dishes and in the center of each Petri dish was inoculated 0.1 $\mu \mathrm{L}$ suspension of spores of the three activated fungal strains in the Sabouraud to obtain a concentration of $10^{5}$ spores $/ \mathrm{mL}$. The control sample consisted of a plate with culture media without essential oils. All experiments were carried out in 3 replicates.

\section{Results}

\subsection{Essential oils yield}

Characteristics and yield of essential oil varies from species to species. The essential oil from the leaves of L. multiflora is in light yellow, with a persistent odor and a yield of $1.2 \%$. The essential oil obtained from the leaves of M. leucadendron is the blade in colour, with a pleasant odour and yield is of $0.9 \%$ (Table 1).

Table 1 Physical characteristics and yields of essential oils

\begin{tabular}{|ccc|}
\hline Essential oil & L. multiflora & M. leucadendron \\
\hline Color & Light yellow & Blade \\
\hline Odour & Persistent and pleasant & pleasant \\
\hline Yield $(\%)$ & 1.2 & 0.9 \\
\hline
\end{tabular}

\subsection{Chemical composition of essential oils}

The results of the chemical analyses of M. leucadendron and $L$. multiflora essential oils samples are presented in table 2. According to the obtained results, both essential oils are characterized by their richness in oxygenated monoterpenes. The essential oil of $M$. leucadendron consists of compounds divided into three terpene groups viz., $47.7 \%$ oxygenated monoterpenes, $16.3 \%$ hydrocarbon monoterpenes, and $13.4 \%$ oxygenated sesquiterpenes. In the group 
Table 2 Majority compounds of the essential oils studied

\begin{tabular}{|c|c|c|c|c|}
\hline Compounds & $\mathrm{IR}^{\mathrm{a}}$ & $\mathrm{IR}^{\mathrm{b}}$ & M. leucadendron & L. multiflora \\
\hline \multicolumn{3}{|c|}{ Hydrocarbon monoterpenes } & 16.3 & 11.8 \\
\hline$\alpha$-pinene & 936 & 1011 & 12.5 & 1.0 \\
\hline Sabinene & 975 & 1044 & - & 3.5 \\
\hline$\beta$-pinene & 982 & 1104 & 2.8 & \\
\hline Myrcene & 991 & 1132 & - & 0.5 \\
\hline$\alpha$-phellandrene & 1004 & 1154 & - & 6.8 \\
\hline Limonene & 1030 & 1187 & 1.0 & \\
\hline \multicolumn{3}{|c|}{ Oxygenated monoterpenes } & 47.7 & 63.6 \\
\hline 1,8 cineole & 1036 & 1209 & 38.2 & 11.4 \\
\hline$\gamma$-terpinene & 1060 & 1232 & 0.3 & \\
\hline Linalol & 1097 & 1552 & - & 6.5 \\
\hline$\alpha$-terpineol & 1194 & 1696 & 9.2 & 4.2 \\
\hline Neral & 1242 & 1699 & - & 18.7 \\
\hline Geranial & 1272 & 1715 & - & 22.8 \\
\hline \multicolumn{3}{|c|}{ Oxygenated sesquiterpenes } & 13.4 & - \\
\hline Viridiflorol & 1614 & 1817 & 13.4 & - \\
\hline
\end{tabular}

$I R^{a}=$ RetentionIndex on non polar HP5colunn ; IR ${ }^{b}$ CalculatedRetentionIndex

Table 3 Macroscopic and microscopic characteristics of isolated strains

\begin{tabular}{|c|c|c|c|c|c|c|c|}
\hline \multicolumn{4}{|c|}{ Macroscopic characteristics } & \multicolumn{3}{|c|}{ Microscopic characteristics } & \multirow{2}{*}{$\begin{array}{l}\text { Identified } \\
\text { Genera }\end{array}$} \\
\hline $\begin{array}{l}\text { Colonies } \\
\text { aspects }\end{array}$ & Colony shape & $\begin{array}{l}\text { Back color } \\
\text { of the back }\end{array}$ & Reverse & Hyphae & Spore shape & $\begin{array}{l}\text { Organization of } \\
\text { conidial heads }\end{array}$ & \\
\hline Fluffy & Invasive & Whitish & $\begin{array}{c}\text { Does not } \\
\text { penetrate agar }\end{array}$ & $\begin{array}{l}\text { Not partitioned } \\
\text { with rhizoids }\end{array}$ & Spherical & Brush shape & Rhizopus sp. \\
\hline Powdery & $\begin{array}{l}\text { Invasive but } \\
\text { slow }\end{array}$ & Greenish & $\begin{array}{c}\text { Does not } \\
\text { penetrate agar }\end{array}$ & Partitioned & Spherical & Brush shape & Aspergillus sp. \\
\hline Pastey & $\begin{array}{l}\text { Invasive but } \\
\text { very slow }\end{array}$ & $\begin{array}{l}\text { Pink white } \\
\text { with age }\end{array}$ & $\begin{array}{c}\text { Does not } \\
\text { penetrate agar }\end{array}$ & Partitioned & Fusiformity & Crescent shape & Fusarium sp \\
\hline
\end{tabular}

of oxygenated monoterpenes, 1,8-cineole with a content of $38.2 \%$ and $\alpha$-terpineol $(9.2 \%)$ were the most represented terpenic elements. $\alpha$-Pinene $(12.5 \%)$ is the most important hydrocarbon monoterpene. This essential oil is also composed of sesquiterpenes such as viridiflorol (13.4\%).

Similarly, the essential oil extracted from L. multiflora also revealed the predominance of oxygenated monoterpene compounds $(63.6 \%)$ such as $41.5 \%$ citral $(18.7 \%$ neral and $22.8 \%$ geranial) and 1,8 Cineole $(11.4 \%)$. However, it is relatively unlikely to be composed of hydrocarbon monoterpenes. $\alpha$-Phellandrene (6.8\%) and sabinene $(3.5 \%)$ were also the most representative hydrocarbon components identified from these two essential oils.

\subsection{Identification of fungal strain}

The macroscopic and microscopic characteristics of the different fungal strains isolated from sweet potato roots grown on Sabouraud are grouped in Table 3 .

\subsection{Antifungal activity of isolated essential oils}

The antifungal activities of isolated essential oils were recorded as mycelial growth inhibition and spore germination inhibition against all three selected three fungal pathogens viz., Rhizopus sp., Aspergillus sp., and Fusarium sp. Both essential oils exhibited significant antifungal activities against the isolated pathogens and it varies against the essential oil concentration.

\subsection{Effect of $L$. multiflora essential oil on isolated fungal strains}

The effects of different essential oil concentrations on the inhibition percentage of fungus are shown in figure 1 . In the case of L. multiflora essential oil, the highest inhibition (100\%) for all the isolated pathogen was observed at concentration $\mathrm{C} 3$ $(0.33 \mu \mathrm{L} / \mathrm{mL})$ after 7 days of incubation. Similar results were observed for concentration $\mathrm{C} 4(0.666 \mu \mathrm{L} / \mathrm{mL})$ while the lowest inhibition was obtained with $\mathrm{C} 1(0.066 \mu \mathrm{L} / \mathrm{mL})$. These results 


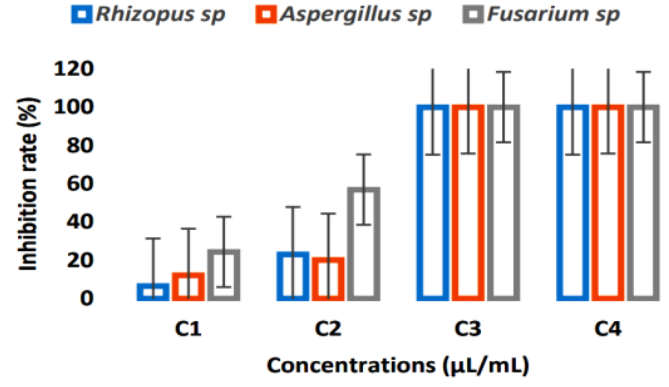

Figure 1: Inhibition rate of mycelial growth of Rhizopus sp, Aspergillus sp and Fusarium sp at different concentrations of $\mathrm{L}$. multiflora essential oil : $\mathrm{C} 1=0.066 \mu \mathrm{L} / \mathrm{mL} ; \mathrm{C} 2=0.166 \mu \mathrm{L} / \mathrm{mL}$; $\mathrm{C} 3=0.333 \mu \mathrm{L} / \mathrm{mL} ; \mathrm{C} 4=0.666 \mu \mathrm{L} / \mathrm{mL}$

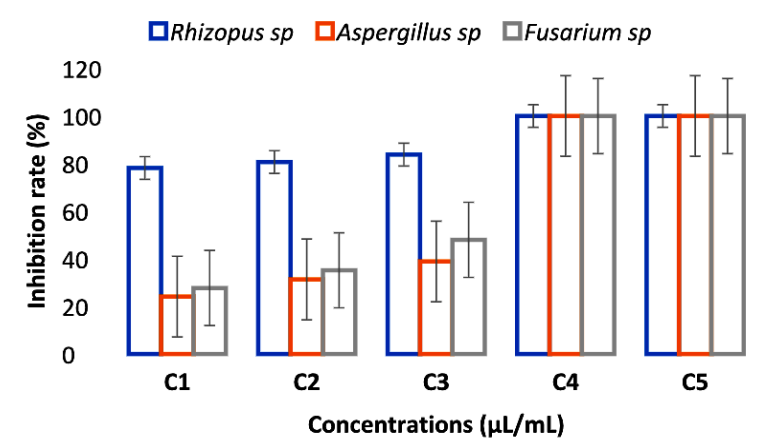

Figure 2 : Inhibition rate of mycelial growth Rhizopus sp, Aspergillus $\mathrm{sp}$, Fusarium $\mathrm{sp}$ at different concentrations of $\mathrm{M}$. leucadendron essential oil : $\mathrm{C} 1=2.66 \mu \mathrm{L} / \mathrm{mL} ; \mathrm{C} 2=5.33 \mu \mathrm{L} / \mathrm{mL} ; \mathrm{C} 3=12 \mu \mathrm{L} / \mathrm{mL}$; $\mathrm{C} 4=24 \mu \mathrm{L} / \mathrm{mL} ; \mathrm{C} 5=48 \mu \mathrm{L} / \mathrm{mL}$

Table 4 Minimum inhibitory and fungicidal concentrations of essential oils of L. multiflora and M. leucadendron

\begin{tabular}{|ccccc|} 
Strains & \multicolumn{2}{c}{ Lippia multiflora } & \multicolumn{2}{c|}{ Melaleuca leucadendron } \\
& $\begin{array}{c}\mathrm{MIC} \\
(\mu \mathrm{L} / \mathrm{mL})\end{array}$ & $\begin{array}{c}\mathrm{MFC} \\
(\mu \mathrm{L} / \mathrm{mL})\end{array}$ & $\begin{array}{c}\mathrm{MIC} \\
(\mu \mathrm{L} / \mathrm{mL})\end{array}$ & $\begin{array}{c}\mathrm{MFC} \\
(\mu \mathrm{L} / \mathrm{mL})\end{array}$ \\
\hline Rhizopus & 0.33 & - & 24 & $\mathrm{nd}$ \\
\hline Aspergillus & 0.33 & 0.33 & 24 & $\mathrm{nd}$ \\
\hline Fusarium & 0.33 & - & 24 & $\mathrm{nd}$ \\
\hline
\end{tabular}

MIC: minimum inhibitory concentration; $\mathbf{M F C}:$ minimum fungicide concentration indicate that the percentage inhibition of mycelia growth increased with increasing concentration of L. multiflora essential oil for all fungus tested.

\subsection{Effect of M. leucadendron essential oil on isolated fungal} strains

The effects of different concentrations of M. leucadendron essential oils on the inhibition percentage of fungus are shown in figure 2 . The highest inhibition (100\%) of mycelial growth for all the isolated pathogen was observed at concentration C4 (24 $\mu \mathrm{L} / \mathrm{mL}$ ) after 7 days of incubation. However, in the case of various fungal isolates, highest $(78.17 \%)$ inhibition was observed for Rhizopus sp. at the lowest concentration $\mathrm{C} 1(2.66 \mu \mathrm{L} / \mathrm{mL})$. The results of the study revealed that Rhizopus sp. showed high sensitivity to M. leucadendron essential oil at all concentrations. The lowest inhibition was observed in the concentration of $\mathrm{C} 1$ $(2.66 \mu \mathrm{L} / \mathrm{mL}), \mathrm{C} 2(5.33 \mu \mathrm{L} / \mathrm{mL})$, and $\mathrm{C} 3(12 \mu \mathrm{L} / \mathrm{mL})$ on Aspergillus sp and Fusarium sp.

\subsection{Minimum inhibitory and fungicidal concentration of essential oils}

The results of study showed that both tested essential oils have varied degrees of inhibition in mycelial growth. The minimum inhibitory concentration (MIC) for Aspergillus sp., Rhizopus sp., and Fusarium sp., was $0.33 \mu \mathrm{L} / \mathrm{mL}$ and $24 \mu \mathrm{L} / \mathrm{mL}$ for L. multiflora and $M$. leucadendron respectively (Table 4). The minimum fungicidal concentration (MFC) for Aspergillus sp., was 0.33 $\mu \mathrm{L} / \mathrm{mL}$ and this concentration was fatal for Aspergillus sp., (Table 4). This indicated that this oil has a fungistatic effect on Aspergillus sp.

\subsection{Inhibition of spore germination}

Data presented in table 5 revealed that the reduction in spore germination was reported with the increasing essential oil concentration. The highest essential oil concentration of both oils tested caused the most profound reduction of spore germination. The highest reduction in spore germination was reported in $L$. multiflora oil which completely inhibited the spore germination of all test fungal strains at $0.66 \mu \mathrm{L} / \mathrm{mL}$ concentration. Conversely, $M$. leucadendron essential oil gave a moderate reduction in spore germination at the lowest concentration of oil. Total inhibition of

Table 5 Inhibition of spore germination by essential oils

\begin{tabular}{|c|c|c|c|c|c|c|c|c|c|c|c|}
\hline \multirow{2}{*}{ Strains } & \multicolumn{5}{|c|}{ L. multiflora $(\mu \mathrm{L} / \mathrm{mL})$} & \multicolumn{6}{|c|}{ M. leucadendron $(\mu \mathrm{L} / \mathrm{mL})$} \\
\hline & Control & 0.06 & 0.16 & 0.33 & 0.66 & Control & 2.66 & 5.33 & 12 & 24 & 48 \\
\hline Rhizopus sp & + & + & + & - & - & + & + & + & + & - & - \\
\hline Aspergillus sp & + & + & + & + & - & + & + & + & + & - & - \\
\hline Fusarium sp & + & + & + & - & - & + & + & + & + & - & - \\
\hline
\end{tabular}

Journal of Experimental Biology and Agricultural Sciences http://www.jebas.org 
spore germination was reported at $24 \mu \mathrm{L} / \mathrm{mL}$. These results show that $L$. multiflora essential oil has a higher fungitoxicity against all three fungal strains.

\section{Discussion}

The average yield of $L$. multiflora leaves essential oil after extraction is $1.2 \%$, which is similar to the report of Tia (2012) those who obtained a similar yield (1.2\%) from L. multiflora leaves. Similarly, Kouamé et al. (2008) reported the yield of $L$. multiflora leaves between 0.8-1.3\%. Also, a higher essential oil yield $(0.9 \%)$ was obtained with $M$. leucadendron. Rokhaya et al. (2017) obtained a similar essential oil yield from Senegalese species. In this study, the components of M. leucadendron essential oil were identified. Among various reported compounds, 1.8 cineole, $\alpha$-terpineol, $\alpha$-pinene, and viridiflorol were the major components. In a recent report on the chemical composition and biological activity of the essential oil of $M$. leucadendron, various authors confirm the high terpenoids contents (Pino et al., 2010; Pujiarti et al., 2012; Tia et al., 2013; Rokhaya et al., 2017). The oil of L. multiflora was characterized by the high proportion of oxygenated monoterpenes with a predominance of citral. These results are contradictory to the findings of Tia et al. (2011) and Soro et al. (2015), those who reported predominance of oxygenated terpenes such as linalol, (E)-Nerolidol and thymol in the essential oil of L. multiflora from Yamoussoukro and Bondoukou respectively. Also, 1.8 cineole at a rate of $60.5 \%$ was previously detected by Owolabi et al. (2009). In addition, in this study, citral and 1.8 cineole, with respective proportions of $41.5 \%$ and $11.4 \%$ were the main molecules of L. multiflora oil. Similar results were obtained by Soro et al. (2015) on the same species from Abidjan and Toumodi in Côte d'Ivoire. The variations in composition observed in the essential oil of L. multiflora can be justified by the geographical origin and physiological state of the plant.

The results of the sanitary analysis of sweet potato roots showed the presence of several types of mould fungus such as Fusarium, Rhizopus and Aspergillus colonize the roots. Concerning the main genera identified, the results of the current study are in agreement with those obtained by Dao (2013), who worked on 116 seed samples of local maize cultivars collected from farmers in Burkina Faso in different locations. These cosmopolitan fungi, especially in tropical and subtropical regions, are the most common and frequently isolated from stored foods (Laouid \& Neftia, 2007).

In this study, antifungal effects of two essential oils including $L$. multiflora and $M$. leucadendron was evaluated against three rootborne fungi of Ipomea batatas and determined their mycelial growth inhibition rate, minimum inhibitory concentration, and minimum fungicidal concentration.
It was observed that $L$. multiflora oil completely inhibited the mycelial growth of the selected fungi at $0.33 \mu \mathrm{L} / \mathrm{mL}$ concentration. Furthermore, this essential oil also inhibited complete spore germination of all isolated fungal strain. The inhibitory activity of L. multiflora essential oil against fungal pathogens was also reported by various authors (Bassolé \&Juliani, 2012; Tiendrebeogo et al., 2017; Cissé et al., 2019). This antifungal activity of $L$. multiflora oil probably depends on the major components citral $(41.5 \%)$ and 1,8 -Cineole (11.4\%).

As result, the essential oil of $M$. leucadendron also has acceptable antifungal properties against the isolated pathogens. The efficacy of these essential oils was positively correlated with the concentration. M. leucadendron oil has complete inhibition and highly effective against the mycelial growth and spore germination at $24 \mu \mathrm{L} / \mathrm{mL}$ concentration. These results are in agreement with those reported by Doumbouya et al. (2012) which show that the essential oil of the genus M. leucadendron has a weak action on $F$. oxysporum and Pythium sp. Similar results have been reported by Camara et al. (2010) when they tested a high concentration of $M$. leucadendron essential oil against Deightoniella. Indeed, the strains studied do not have the same sensitivity to the essential oils tested. This could be explained by the diversity of membrane components of each microorganism and by the chemical composition of each plant species (Yen \& Chang, 2008).

The fungitoxicity of $M$. leucadendron oil can be accredited to the most abundant components 1,8-cineole, $\alpha$-Pinene, $\alpha$-terpineol. These monoterpenes had been earlier reported for their antifungal properties as part of many essential oils (Sartorelli et al., 2007; Liu et al., 2008; Gudrun \& Gerhard, 2012; Tabassum \& Vidyasagar, 2013).

The essential oil of L. multiflora and M. leucadendron have a particular chemical composition. It contains a high proportion of oxygenate compounds. Several previous studies have shown that essential oils rich in terpenoids may have antifungal properties (Tiendrebeogo et al., 2017; Ouoba et al., 2018;). Monoterpenes could act on permeability but also other functions in cell membranes, thereby disrupting membrane exchanges (Cristani et al., 2007; Russo et al., 2013). This gives them different modes of action on several types of fungi that cause food spoilage (Aoudou et al., 2010). 1,8-cineole was found to be highly capable of eliminating the fungal pathogens by altering the structure and moisture of mucous membranes of fungal cells and interrupting the respiratory processes (Andriole, 1994). Various monoterpnes with antimicrobial potencies such as $\alpha$-pinene, $\alpha$-terpineol, and citral have antifungal and antibacterial activities (Zhou et al., 2014; Mahizan et al., 2019). These components seem to be contributing to the total efficiency. According to Grbic et al. (2011), the constituents of essential oils interact with the absorption of nutrients from the environment, which affects the mycelial growth of fungi. They operate on mycelial hyphae, loss of rigidity, and 
integrity of the hyphae cell wall, resulting in the death of the mycelium (Sharma \& Tripathi, 2008).

The essential oils of L. multiflora and M. leucadendron have shown the potential to inhibit spore germination. Complete inhibition $(100 \%)$ of spore germination was obtained with $L$. multiflora $(0.66 \mu \mathrm{L} / \mathrm{mL})$ and $M$. leucadendron $(24 \mu \mathrm{L} / \mathrm{mL})$. The results of the present study are in agreement with the previous findings which indicate that essential oils can inhibit fungal spore germination (Grbic et al., 2011; Doumouya et al., 2012). According to Chitarra (2003), the active metabolism that occurs during spore germination is respiration, RNA, and protein synthesis. These vital mechanisms can be inhibited by essential oils that can penetrate, disrupt fungal cell walls and cytoplasmic membranes (Grbic et al., 2011). This will damage and permeate mitochondrial membranes (Akthar et al., 2014).

Major components are usually found to be responsible for the antimicrobial activities of essential oils. But sometimes the minor and trace components may also play a significant role in synergistic and antagonistic interactions to influence the total activity of the oil (Ismail et al., 2013). Referring to the values of the minimum fungicidal concentrations of each of these oils used, the study revealed that $L$. multiflora oil is the most toxic. Tests should be considered under actual tuberous root storage conditions to assess its biological efficacy on the major fungal strains that colonize these roots. This could lead to the practical use of these essential oils as an alternative solution in integrated systems for the protection of sweet potato tuberous roots in Côte d'Ivoire.

\section{Conclusion}

The investigation of the antifungal activity of the tested of $L$. multiflora and M. leucadendron essential oils against three phytopathogenic fungi (Rhizopus sp., Fusarim sp., and Aspergillus sp.) associated with Ipomea batatas tuberous showed that both oils have antifungal effects. The results of this study indicate the high effect was observed with $L$. multiflora oil which provides complete inhibited on mycelial growth of Fusarium sp., Rhizopus sp. and Aspergillus sp. at $0.33 \mu \mathrm{L} / \mathrm{mL}$ concentration strains tested. This antifungal activity of $L$. multiflora oil probably depends on the major components. In this case of Melaleuca oil, a higher concentration was needed for inhibition. Both essential oils could be used as food preservatives in some food products where fungal strain can grow and can spoilage the product. Further research is needed on safety issues namely, on the effect of natural antifungal in field condition.

\section{Acknowledgements}

The authors of this work would like to thank the "glyco and nano vector for therapeutic screening" team at the Max Mousseron
Biomolecules Institute (IBMM) of the University of Montpellier 1 for the chemical characterization of essential oils.

\section{Conflicts of interest}

We have no conflict of interest to declare.

\section{References}

Adams RP (ed.) (2007) Identification of Essential Oil Components by Gas Chromatography/Mass Spectrometry, 4th edn. Allured: Carol Stream, IL

Akthar MS, Degaga B, Azam T (2014) Antimicrobial activity of essential oils extracted from medicinal plants against the pathogenic microorganisms: A review. Biological Sciences and Pharmaceutical Research 2: 001-007.

Andriole VT (1994) Current and future anti fungal therapy: New targets antifungal agents. Journal of Antimicrobial Chemotherapy $44: 151-162$

Anonymous (2009) National report on the state of phylogenetic resources for food and agriculture. Republic of Côte d'Ivoire, Pp. 64.

Aoudou Y, Léopold TN, Pierre MJD, Xavier FE, Moses MC (2010) Antifungal properties of essential oils and some constituents to reduce food borne pathogen. Journal of Yeast and Fungal Research 1: 001-008.

Bassolé IHN, Juliani HR (2012) Essential oils in combination and their anti microbial properties. Molecules 17: 3989-4006.

Broydé H, Doré T (2013) Effets des pratiquesagricoles sur la contamination des denrées par les mycotoxines issues de Fusarium et Aspergillus spp. Cahiers Agricultures 22: 182-194

Camara B, Dick E, Sako A, Kone D, Kanko C, Boye MAAD, Ake S, Anno A (2010) Biological control against Deightoniella torulosa (Syd) Ellis, by applying essential oils of Eucalyptus platyplylla F. Muell. and Melaleuca quinquenervia L. Phytotherapy 8: 240-244.

Chitarra GS (2003) Germination inhibitors of fungal spores: identification and modeof action., $\mathrm{PhD}$ thesis submitted to the University of Wageningen, The Netherlands, Pp. 110.

Cissé M, Tia VE, N'guessan AE (2019) Extraction and evaluation of chitosan enhanced by Lippia multiflora essential oil on postharvest of tomato. International Journal of Environmental \& Agriculture Research 5:1-8 
Cristani M, Arrigo M, Mandalari G, Castelli F, Sarpietro MG, Micieli D, Venuti V, Bisignano G, Saija A, Trombetta D (2007) Interaction of four monoterpenes contained in essential oils with model membranes: implications for their antibacterial activity. Journal Agricultural and Food Chemistry 55: 6300-6308.

Dao K (2013) Study of the variability of Fusarium verticillioides (Sace) Nirenberg isolated from peasant maize seeds in Burkina Faso and research into alternative control methods based on aqueous extracts. Final thesis submitted for the Diploma of Advanced Studies in Integrated Natural Resources Management. Institute of Rural Development (IDR) of the Polytechnic University of Bobo-Dioulasso, Burkina Faso, Pp. 53.

Domsch, KH, Gams W, Anderson TH (2007) Compendium of Soil Fungi. 2nd Ed. IHW-Verlag Echin, Pp. 672.

Doumbouya M, Abo K, Lepengue AN, Camara B, Kanko K, Aidara D, Kone D (2012) Comparative in vitro activity of two synthetic fungicides and two essential oils on soil fungi from vegetable crops in Côte d'Ivoire. Journal of Applied Biosciences 50: 3520-3532.

Elkak A, El Atat O, Habib J, Abbas M (2012) Occurrence of aflatoxin M1 in cheese processed and marketed in Lebanon. Food Control 25: 140-143.

Grbic ML, Stupar M, Vukojević J, Grubišić D (2011) Inhibitory effect of essential oil from Nepeta rtanjensis on fungal spore germination. Central European Journal of Biology 6: 583-586.

Gudrun L, Gerhard B (2012) A review on recent research results (2008-2010) on essential oils as antimicrobials and antifungals. A review. Flavourand Fragrance Journal 27: 13-39.

Ismail A, Lamia H, Mohsen H, Samia G, Bassem J (2013) Chemical composition and antifungal activity of three anacardiaceae species grown in Tunisia. Science International 1: 148-154.

Kouamé RO, Yolou S, Boti JB, Kouadio GN, Coffi K, Coffy A, Casanova J (2008) Chemical study and antidiarrheal activity of the essential oils of two aromatic plants of the Ivorian Pharmacopoeia. European Journal of Scientific Research 24: 94-103.

Laouid A, Neftia H (2007) Isolation and identification of storage fungi for groundnuts grown in Oued-Souf. Final thesis submitted for the post-graduate diplomain biology, Kasdi-Ouargla University, Algeria, Pp. 88.

Liu X, Chen Q, Wang Z, Xie L, Xu Z (2008)Allelopathic effect of essential oil from Eucalyptus grandis $\mathrm{x}$ E. urophylla on pathogenic fungi and pestinsect. Frontier of Forestry in China $3: 232-236$.
Mahizan NA, Yang SK, Moo CL, Song AAL, Chong CW, Abushelaibi Lim SH, Lai KS (2019) Terpene derivatives as a potential agent against anticrobial resistance (AMR) pathogens. Molécules 24: 2631.

McLafferty FW (1989) Registry of mass spectral data. 5th ed. New York: Wiley.

Nasser AL (2001) Fungal contamination of white cheese at the stage of consumption in Saudi Arabia. Pakistan Journal Biological Sciences 4: 733-735.

Ndangui BC (2015) Production et caractérisation de farine de patatedouce (Ipomoeabatatas.Lam) : optimisation de la technologie de panification. Thèse de Doctorat, l' Université de Lorraine (France), 143 p.

Nepa (Center for Food Studies and Research) (2006) Brazilian Table of Food Composition (2nd Edn), FórmulaEditora, Campinas, Pp. 113.

Ouoba P, Ouattara L, Bonzi S, Yameogo JT, Somda I (2018) Evaluation of antifungal activity and phytotoxicity of the essential oil of Zanthoxylum zanthoxyloides fruits. Agricultural Science Research Journal 8: 92-99.

Owolabi MS, Ogundajo A, Lajidé L, Oladimeji MO, Setzer WN, Palazzo MC, (2009) Chemical composition and antibacterial activity of essential oil of Lippia multiflora Moldenke from Nigeria. Records of Natural Product 3:170-177.

Pandey DK, Tripathi NN, Tripathi RD, Dixit SN (1982) Fungitoxic and phytotoxic properties of the essential oil of $H$. suaveolens. Journal of Plant Diseases and Plant Protection 89 :344-349.

Pino AJ, Erick LR, José LR, Miguel DF (2010) Phytochemical analysis and in vitro Free-Radical-Scavenging Activities of the Essential oils from Leaf and Fruit of Melaleuca leucadendron L. Chemistry and Biodiversity 7: 2281-2288.

Pujiarti R, Ohtani Y, Widowati TB, Widowati TB, Kasmudjo (2012) Utilization of Essential Oil. Wood Research Journal 2: 94-99.

Rokhaya F, Saliou N, Dienaba S, Mbacké S, Abdoulaye S (2017) Chemicalcharacterization of essential oilfrom the leaves of Callistemon viminalis (DR) and Melaleuca leucadendron (Linn.). Asian Pacific Journal of tropical Biomedecine 7 :347-351.

Rosales AM, Mew TW (1997) Suppression of Fusarium moniliforme in rice by rice associated antagonistic bacteria. Plant Disease 81:49-52.

Russo M, Suraci F, Postorino S, Serra D, Roccotelli A, Agosteo GE (2013) Essential oil chemical composition and antifungal effects on Sclerotium cepivorum of Thymus capitatus wild 
populations from Calabria, southern Italy. Brazilian Journal of Pharmacognosy 23: 239-248.

Samson RA, Hoekstra ES, Van Oorschot CAN (2004) Introduction to Food Borne Fungi. 7th Ed., Centraal bureau Voor Schimmel cultures, Utrecht.

Sartorelli P, Marquioreto AD, Amaral-Baroli A, Lima MEL, Moreno PRH (2007)Chemical composition and antimicrobial activity of the essential oils from two species of Eucalyptus. Phytotherapy Research 21:231-233.

Sharma N, Tripathi A (2008) Effects of Citrus sinensis (L) Obseckepecarp essential oil one growth and morphogenesis of Aspergillus Niger (L) Van Tieghem. Microbiological Research 3: 337-344.

Soro LC, Grosmaire L, Atchebri AOOL, Munier S, Menut C, Pelissier Y (2015)Variability in the chemical composition of the essential oil of Lippia multiflora leaves grown in Côte d'Ivoire. Journal of applied Biosciences 88: 8180-8193.

Tabassum N, Vidyasagar GM (2013) Antifungal investigations on plantessential oils. A review. International Journal Pharmacy and Pharmaceutic Sciences 5:19-28.

Tia VE (2012) Insecticidal power of essential oils of five aromaticspecies of ivory coast in the control of phytophagous insects Bemisia tabaci G. and Plutella xylostella L: chemical composition and efficacy test. Doctoral thesis submitted to the Félix Houphouët Boigny Abidjan University (formerly Cocody University). Pp. 144.

Tia VE, Adima AA, Niamké LS, Gnago AJ, Martin T, Lozano P, Chantal M (2011) Chemical composition and insecticidal activity of essential oil of two aromatic plants from Ivory Coast against Bemisia tabaci G. (Hemiptera: Aleyrodidae). Natural Product Communications 6: 1833-1838.

Tia VE, Lozano P, Menut C, Lozano F Y, Martin T, Niamke S, Adima, AA (2013)Potentiality of essential oils in the organic fight against the white fly Bemisia tabaci Genn. Phytotherapy11: 3138.

Tiendrebeogo A, Ouedrago L, Bonzi S, Kassankogno AL (2017) Study of the activity of Cymbopogon citratus (DC.) extract Stap, Eclipta alba L., Lippia multiflora. M. and Agave sisalana P. International Journal of Biological and chemical Sciences 11 :1202.

Tomal JH, Welch WJ, Zamar RH (2015) Ensembling classification modelsbased on phalanxes of variables with applications in drug discovery. The annals of Applied Statistics 9: 69-93

Yan L, Mu T, Sun H, Zhang M (2014) Digestibility and structural Properties of Thermal and High Hydrostatic pressure Treated Sweet Potato (Ipomoea batatas L) Protein. Plant Foods Human Nutrition $69: 270-275$.

Yen TB, Chang ST (2008) Synergistic effects of cinnamaldehyde in combination with eugenol against wood decay fungi. Bioresource Technology 99: 232-236.

Zannou A, Gbaguidi MAN, Dahouenon EA (2017) Synthesis of research on sweet potato (Ipomoea batatas) with a view to its valorization: A review. International Journal of Chemical Science 1: 84-89.

Zhou H, Jia L, Tao N (2014) Antifungalactivity of citral, octanol and $\alpha$-Terpinéol against Geotrichum citri aurantii. Food Control $37: 227-283$. 